\title{
Islamic radicalization in the Maldives: An analysis of the role of religious networks and proliferation of different religious narratives
}

\author{
Aishath Shama* \\ Institute of Diplomacy and International Studies, Rangsit University, Rangsit, Thailand
}

\author{
Keywords \\ Islamic radicalization \\ Maldives \\ Religious networks \\ Radical interpretation of Islam \\ Jihad
}

Received: 15 August 2018

Accepted: 19 September 2018

Published: 31 October 2018

\begin{abstract}
The main objective of this paper is to analyze the role of religious Non-Government Organizations (NGOs) and the proliferation of different religious narratives in creating an enabling environment for the penetration of radical interpretations of Islam and thereby contribute to the radicalization of vulnerable individuals. Furthermore, it also addresses the lack of action and balancing counter-religious narratives from concerned official authorities and moderate religious scholars. The Maldives is experiencing a rise in non-violent and violent forms of Islamic radicalization and the task of dealing with returning Jihadists. Despite the paucity of existing literature on the subject and the sensitivity of the subject at the national level, this study attempts to explore the role of religious NGO's and the proliferation of different religious narratives in creating an enabling environment for the penetration of radical interpretations of Islam. Thus this study uses a simple qualitative research method to analyze how these factors contribute to the radicalization of vulnerable individuals in the Maldives. The findings of the study reveal that in the context of the Maldives, fragmentation of religious narratives, lack of balancing counter-arguments against radical ideologies, lack of monitoring of content with extreme views, and relevant action against local religious networks disseminating such views create an enabling environment for radical religious ideologies to flourish.
\end{abstract}

(C) 2018 The Author(s). Published by TAF Publishing.

\section{INTRODUCTION}

\section{Background and Motivation}

Since the $9 / 11$ terrorist attacks radicalization as a concept has renewed widespread attention among both the security and academic circles trying to understand the underlying processes whereby individuals and groups move towards terrorist activities. While there is no universal consensus on the definition of radicalization the general understanding of the concept has been described as a process where by an individual or group turn to violence using an ideological or religious justification (Azhar, 2015; Patel, 2011).

The Maldives is a small archipelago state consisting of 1192 islands of which only 188 island are inhabited. The islands are scattered roughly across $90,000 \mathrm{sq} \mathrm{km}$ making the nation one of the most disparate countries in the world. Islam has been practiced as the sole State religion for the past 800 years.

In the Maldives strands of extreme religious ideologies were visible as early as the 1990's but, when on 29 September 2007, an Improvised Explosive Device (IED) was detonated near Sultan Park (a recreational park and a major tourist attraction) in the capital city Male', the incident came out as a huge shock to most citizens of the country. This was the first and only terror attack in the Maldives, in which 12 tourists were hurt and three victims suffered burns of various extents. Soon after the incident, a group of more than 50 people was arrested after security forces confronted and dismantled a temporary mosque used by radicals to conduct prayers in Himandhoo, an island about 50 miles from the capital city Male'.

In recent years, it has also been observed that a number of Maldivian youth taking up the call to join the global jihad in

*corresponding author: Aishath Shama

†email: shama.aishath@gmail.com 
conflict areas such as Syria. According to "Country Reports on Terrorism 2015" published by United States Department of States, since 2010 there has been an increase in the number of Maldivians who support violence and are involved in transnational terrorist groups (Country Reports on Terrorism 2015, 2016). While there is no general consensus on the number of Maldivians who had departed the country to join Jihadist militant groups the official government figure oscillates between 20 to 100 individuals.

Coming into the post authoritarian period on top of the existing societal problems such as unemployment, housing crisis, drug problem, gang culture and others, the Maldives has also been faced with ongoing periods of political unrest with both the ruling regime as well as the political opposition using religious rhetoric to outbid each other. The dangerous mix of political instrumentalization of Islam, grievances and perceived injustices also has created space for radical elements such as radical religious networks to flourish and capitalize on the grievances of such vulnerable individuals and mobilize them for violent activities.

\section{Research Objectives}

In the Maldives the establishment of democratic values in 2005 gave a voice to different groups within the society whose voices were previously subdued. As such not only political activism started functioning more transparently and openly but also Islamic activism flourished. The freedoms ushered in by the democratization process also allowed legal precedent to the formation of NGO's both political and religious. This also gave a strong resolve to certain religious groups from the far-right who were separatist from the mainstream to expand their base operations and preach to a wider audience and gain more followers.

Thus, the main objective of this paper is to analyze the role of religious NGOs and proliferation of different religious narratives in creating an enabling environment for the penetration of radical interpretations of Islam and thereby contribute to radicalization of vulnerable individuals. Furthermore, it also addresses the lack of action and balancing counter-religious narratives from concerned official authorities as well as moderate religious scholars. As such this paper addresses the following questions.

1) What are the activities carried out by religious NGOs?

2) How do activities by religious NGOs contribute to Islamic radicalization in the Maldives?

3) What is being done by concerned official authorities to address the penetration of radical interpretations of Islam?

\section{LITERATURE REVIEW}

The literature review of this paper is divided into three main parts. The first section briefly presents some of the working definitions and distinction made by various scholars in the terminology of radicalization discourse. The second section explores the role of Social Networks and the third section gives a Maldivian context in which a short overview of the previous studies on Islamic radicalization in the Maldives is presented.

\section{Defining Radicalization}

In the modern usage the concept of radicalization has been associated mostly with "radical Islam" and violence (Alahoul, Azizan, \& Alwi, 2016; Githens-Mazer, Lambert, Baker, Cohen-Baker, \& Pieri, 2010) and denotes a process of human developments that precedes terrorist activity (McCauley \& Moskalenko, 2017).

According to Peter Neumann "radicalization, very simply, is the process whereby people become extremists." In general, extremism has been referred as "political ideas and ideologies that oppose a society's core values and principles" (Neumann, 2011). Given that "radical" is a relative concept radicalization can be categorized as adherence to views, beliefs and actions that are away from that of the mainstream and can be either non-violent or violent.

When applied to Islam, the term radical is often used interchangeably with terms such as fundamentalism, Islamism and even neo-Salafism and Wahhabism (Githens-Mazer et al., 2010; Qianli, 2016). One of the biggest misconceptions about all these ideological and political manifestations is that they are all inherently violent (Ayoob, 2004; Saahar, Sualman, Hashim, \& Mohamed, 2017). According to Ayoob one reason for such assumptions are because more often than not people overlook the context-specificity of how such ideas becomes radical. Pointing out to the cases of Pakistan and Saudi Arabia, Ayoob notes that in the late 1970's and 1980's it was the local circumstances such as "lack of opportunities" and the "impact of Afghan war" in Pakistan and "explosive population growth" and" inflow of massive amounts of petrodollars" in Saudi Arabia that ignited conservative radical elements in these societies rather than a problem with neo-Wahhabist thought itself (Ayoob, 2004). He also further asserted that "it is the local context that has largely determined the development and transformation of Islamist movements within particular national milieus" (Ayoob, 2004). 


\section{Role of Social Networks}

Studies on radicalization also focus on the role of social networks in the process of radicalization. For instance as demonstrated by Social Movement Theories, Social Movement Organizations (SMO) serves as "agitators" and "raise consciousness around issues and help to develop the sense of discontent among the general population" (Christiansen, 2009). In general social movements are defined as "purposeful, organized groups striving to work toward a common goal" (Christiansen, 2009). Studies also show that "collectivistic shift - greater orientation toward one's group and its norms and values" acts an empowering process and strengthens the individuals' commitment towards group goals (Kruglanski \& Webber, 2014). Hence studying the role of social networks such as religious NGO's may shed more insight into the radicalization process.

\section{Previous Studies}

Islamic radicalization, although a term widely used in the media, academia and even in political discourse in the Maldives, is vaguely defined and so far does not have a local context officially established to it. At the national level there are only a handful of academic researches about it and unfortunately there are only a few official collated works published and accessible to the public. National level reports even if written are only disclosed to a selected few among the relevant government authorities. Lack of unanimity at the national level on what exactly "radicalization" is, or the specific parameters for considering an act, activity or a process, "radical" does the search for explanations of radicalization in the context of the Maldives a complex issue of study. According to the few available literature, the rise of global Islamism which is believed to have emerged in the Middle East as an alternative to the western backed autocrats and man-made flawed laws in place of Sharia law surfaced even in Maldives via the Islamic scholars and clerics returning back after education in Islamic Institutes abroad (Naseem \& Mohamed, 2014). In a preliminary assessment of radicalization in the Maldives conducted by local NGO Maldives Democracy Network (MDN), it has been observed that Islamic textbooks and religious materials including religious sermons, religious articles as well as Facebook pages of religious scholars and religious NGOs heavily incites radical religious views and are deemed to contribute to the endorsement of radical views and ideas in the society (Maldives Democracy Network, 2016).

In the modern day context, Islamism has emerged as an antagonist force against the proliferation of liberal democracy which is conflict in with the Islamist views. This globalist Is- lamism has been mirrored in the Maldives with the formalization of underground Islamists networks post democratic reform.

The absence of an official definition of Islamic radicalization at the national level has created misconceptions such as outward changes and appearances of individuals or groups, proliferation of Arabic merchandise and healing methods (Rugya and Hijama) are signs of Islamic radicalism. However, Islam being practiced the sole State religion for the past 800 years is closely tied to the identity of the country. Thus, such overt changes must be classified as cultural imports rather than observing it as a measure of increased conservatism of the Maldivian society. Paucity of empirical research on actual subjects and lack of parameters set to identify or gage when a thought or action can be classified as radical is another dilemma faced when addressing Islamic radicalization in the Maldives. Research also points out that radicalization as a concept can be both violent and non-violent. For example segregated prayer congregations do not involve any violence. However, as per the Religious Unity Act of the Maldives such actions can be deemed as radical as it invokes societal disharmony.

Moreover, it is important to emphasize that not all supporting conservative religious ideals support violence or jihad. But if asked whether religious freedom should be allowed in the Maldives, majority would oppose such an action. As pointed out by the Social Identity theory, when religion is closely tied to the social identity of an individual or group, victimization or injustice towards the in-group can produce such reactions such as intolerance, hatred or even violence towards the out-group (Veldhuis \& Staun, 2009). However, as pointed by the two-pyramids model by Clark McCauley and Sophia Moskalenko this also does not mean that all with radical ideas will manifest it through radical actions (McCauley \& Moskalenko, 2017).

\section{METHODOLOGY}

This study adopts the single case study method to explore and understand the role of religious networks and different religious narratives in contributing to Islamic radicalization of vulnerable individuals in the Maldives.

This study uses both primary and secondary sources of information. Semi-structured interviews are used as the primary source of data collection. The reason for choosing semi-structured interview method is to allow the questions to be flexible and adaptable to the emerging responses and ideas of the respondents. Person-to-person interviews were conducted with relevant stakeholders from the Ministry of Islamic Affairs (MIA), Maldives Police Services 
(MPS), Directorate of Intelligence (MPSDI), Al Asr, (religious NGO) and individual scholars. This study also use relevant books, journal articles and other publications, official statistics and published reports of government databases, NGOs, and also documents from various news and mass media sources as the secondary sources of collecting data.

The data collected in this study are analyzed and interpreted from three perspectives. First this study presents an overview of proliferation of religious networks and briefly explains the various activities carried out by religious NGOs and how it's conducive to dissemination of radical interpretation of Islam. Second this study explores the consequences of promulgation of different religious narratives on the populace. And finally this study also examines why there is a lack of balancing moderate counter-arguments.

\section{RESULTS AND DISCUSSION}

\section{Role of Religious Non-Governmental Organizations}

The transition towards democracy in the Maldives gave a voice to different groups within the society whose voices were previously subdued. This was also evidenced by the growing number of religious NGO's post 2005. Most active NGO's use internet platforms such as Facebook, Twitter, Instagram and Viber groups to disseminate their messages. If popularity and reach of these NGO's is to be measured by the number of followers they have on Facebook or on likes for their posts then comparatively it's high. The messages disseminated mostly concerns religious conduct, piety, guidelines, religious information in forms of fables, lectures and sermons by both local as well as scholars from abroad. Religious NGO's have also been voicing concerns about existing social norms, cultural practices and are heavily engaged in moral policing. For example time and again religious NGO's have issued fatwas declaring music, singing, dancing and celebrations as Haram. In fact a video showing some 24 scholars of Maldives pronouncing music as Haram was uploaded on YouTube in 2012 . Religious conservatives have also been critical of the "anti-Islamic" aspects of the national education curriculum . Recently, several religious NGO's including Jamayathul Salaf (JS) has objected to the subject of the creative arts stating that music is Haram and has even been successful in pressuring the government to declare it as an optional subject (Minivan News, 2015). Thus, over the last decade religious NGO's have played a significant role in bringing social change, which has also manifested through the outward changes in people.

On the other hand one cannot disregard the fact that some of the messages circulated through bite-sized info graphics and even some of the religious lectures and sermons con- tain information that can be perceived radical. Evidence show that some of the religious content circulated contains references inciting religious divides, hatred towards western concepts and also endorsing Jihad. For example Jamiyyathul Bayan a local Islamic NGO criticized Nationalism on one of its Facebook post, which states that "Nationalism is a concept alien to Islam because nationalism calls for unity based on family and tribalistic ties, whereas Islam binds people together on the 'Aqeedah', that is belief in Allah (swt) and His Messenger (saw). Islam calls for the ideological bond." As pointed out by Olivier Roy such narratives calls on for a deculturalization of Islam which is driven by a set of norms unconfined to traditional national boundaries i.e. deterritorialization (Roy, 2018). In another Facebook post shortly after the Ministry of Islamic Affairs described the war in Syria "a civil war", Bayan issued a press statement declaring their stance on the issue by rejecting that the war in Syria as a civil war and endorsing that participation of foreign fighters counts as Jihad.

Furthermore, there are also indications that local NGO's are linked to regional terrorist organizations. The 2004 Indian Ocean Tsunami provided an opening for regional Islamist groups to penetrate into the country under the guise of humanitarian charities and establish underground networks to spread conservative Islam. Idara Khidmat-e-Khalq (IKK), which is affiliated with the Pakistan-based Jammat ud Dawa/Lashkar-e-Taiba are believed to have established connections in the Maldives. According to MPS they have identified a number of financiers, facilitators and recruiters especially for facilitating travel to Syria and Iraq. Facilitators arrange finances, travel and means to communicate with people smugglers based in Turkey to safely move these families into Syria.

\section{Activities Carried Out By Religious NGO's}

Active NGO's travel across the country to conduct religious retreat camps under various names such as Hijra, Tazkiya and Rihla. According to local scholar, Hassan Amir the motive behind such camps is Da'wah - spreading Islam and the names of these camps are symbolic too. Apart from spreading piety, in one aspect such camps can also be considered radical in nature says Amir.

This was also verified by MPS;

"Such religious programs held under the banner of religious teaching and togetherness provides a unique platform for high profile recruiters and radical preachers." (Maldives Police Service, 2018)

General Manager of Al-Asr opined that youth leaving the country for Jihad are mostly motivated by the notion of 
attaining "hero-status". Furthermore, he also noted that they conduct various programs that are based on education and are not specifically religious in nature. However, some of their programs do contain religious elements and if so scholars are invited and paid to take that particular segment.

Religious NGO's also sponsors and organize lectures and sermons by local as well as Islamic scholars from abroad. Controversial preachers such as Zakir Naik and Dr Bilal Philips have been invited to the Maldives on various occasions to deliver lectures on religion. During one such visit to the Maldives in 2009 Dr Bilal Philips reportedly told thousands of Maldivians that regardless of their age once girls reach puberty it was okay to marry them. In the Maldives the legal age for marriage is 18 years. However, no statements were issued by any of the concerned official authorities in response to such a contradictory opinion.

The works of NGO's also transcends to coordinating relief operations and organizing international aid campaigns to raise funds and donations for refugees and victims of war in Syria, Yemen, Palestine, Rohingya and such places. According to Hassan Amir, the Maldivians who are participating in conflict zones are mostly drawn by international events and issues such as Palestine and Syria have a very high traction in the Maldives.

\section{Proliferation Of Different Religious Narratives}

In recent years the proliferation of religious scholars and NGO's with different schools of Islamic thought and diverging religious narratives has also led to "fragmentation and pluralization of the religious discourses" in the Maldives (Minivan News, 2015). Dean of Centre for Postgraduate Studies of Islamic University of Maldives (IUM), Dr. Ibrahim Zakariyya Moosa postulates that the negative consequences of such diverging opinions arise when there is a lack of humbleness in expressing ones view.

"My opinion is that if its religious or any other opinion, there should be humbleness when expressing your views. This will indicate that there are areas where one can explore more and more to find the truth. The ultimate truth may not necessarily be what somebody is propagating. But it's unfortunate when there is an assertion that the ultimate truth lies with me, I am the only authority to pronounce truth. When people are indoctrinated with such views then that's wrong." (Moosa, 2018)

According to MPSD there are endless religious groups currently operating in the Maldives but the most radical groups identified are Jamaat Al Muslimeen, DOT Group of Religious Extremists and The Super Dot, and they operate mostly un- derground. The most prominently active religious NGO's in the Maldives are believed to be Jamiyyathul Salaf (JS) and the Islamic Foundation of Maldives (IFM). Both of these organizations propagate Salafi school of thought and are accused of spreading ultra-conservative religious thought. In a number of instances JS has rejected calls for discussions on religious issues contending that there will be no debates on Islamic penalties. In $2011 \mathrm{JS}$ led protests condemning the remarks made by UN Human Rights Commissioner Navi Pillay's call on the government and the judiciary to issue a moratorium on flogging. JS has also been critical of the new penal code declaring that the "law has been formulated on a secular, liberal basis that is alien to the purposes of Islamic sharia" (Minivan News, 2015). Infiltration of ultra-conservative Islamic ideologies creates fears among the general public, thus creating an environment prone for individuals and groups to internalize such radical thoughts and behaviors. In this regard Dr. Ibrahim Zakariyya Moosa noted that;

"In my opinion in the Maldives Salafi school of thought is very active. Now in Salafi school of thought they focus very must on text. Meaning they take the literal meaning of text. They believe that in no circumstance we can bring change to this text. That is true of course. But the thing is they hardly consider whether this literal meaning align with the broader objectives of Sharia. That is their view. So the problem that arises is that if Muslims build their worldview based on that literal meaning or the face value of the text, then their thought will only process within a very narrow framework. They do not believe in second opinions and they straightout reject it. They believe that only Prophets Companions would only know the true meaning of the texts and they have interpreted the text in this or that way. So anyone who says otherwise is an apostate. Thus, when such thoughts are propagated it creates fears in people because they don't want to be labeled as an apostate or those who has transgressed." (Moosa, 2018)

As numerous scholars points out there are divisions among Salafist themselves . According to Chancellor of Islamic University of Maldives (IUM) and Former Minister of Islamic Affairs, Dr. Mohamed Shaheem Ali Saeed even in the Maldives there are various divisions of Salafi thought.

"There are many schools of thoughts that the Islamic scholars accepts such as Hanafi, Hanbalee, Shaafee and Maliki...Salafi thoughts or Salafism was a much later addition. There are differences among Salafists themselves. Even in the Maldives there is not only one Salafi sector. In my opinion Salafism is becoming more sort of a different 'Mazhab'. And I believe this could be potentially really dangerous. When we allow such 
differences to grow what happens is that from that other various divisions of Salafi thought starts to grow. They believe that other Muslims are not in the right path. This is very sad. So Salafism now is more sort of a totally different sector. In my opinion these different sectors should not be there. We should all refer to ourselves as Muslims or Sunni Muslims. All these sectors create conflicts in our Muslim community." (Saeed, 2019)

The infiltration of this global Islam does not only attempt to re-Islamize the Maldivian society but in parallel it also works to de-secularize it (Minivan News, 2015). For example in 2011, a mob attacked on a 'silent protest' calling for religious tolerance, held at the Artificial Beach to mark Human Rights Day.

\section{Lack of Action And Balancing Counter-Narratives}

In order to address the issue of fragmentation of the religious consciousness a platform needs to be created where various opinion makers and religious ideologues can come together and share ideas and build consensus. In the Maldives what has been noticed is that there is a lack of coordination between the key institutions and stakeholders dealing with this issue. Referring to the conduct of religious camps, Deputy Minister of Ministry of Islamic Affairs, Mohamed Ibrahim noted that there are no official documentations on whether such camps disseminate extreme religious narratives. However, he also noted that some form of extreme religious view surface in islands in which such camps are conducted.

"There are no formal documentations confirming such camps propagate extreme religious ideologies, so it's not easy to talk about it in depth. We only hear rumors. We only get news that some religious $N G O$ is conducting a Rihla camp in some island and conducting programs to disseminate religious information. Whether they spread extreme religious information is not clear so I can't be absolute about it. But we have noticed that some form of extreme religious views surfaces in islands in which such camps have been conducted. We get to know about it when the Ministry receives a phone call from someone in the island clarifying the issue. Then when we check we find out about one or two months ago some program has been conducted by a religious NGO. Usually these extreme views revolves around issues such as vaccination is prohibited in Islam, in schools boys and girls should not enter from the same gate, prohibition of cadet and such activities. So these things are regarded as insignificant but if we don't deal with these issues it can lead to much bigger problems later." (Ibrahim, Deputy Minister of Ministry of Islamic Affairs)
In hopes to curb religious extremism in the country in September 2011 a new religious unity regulations was enforced under the Protection of Religious Unity Act of 1994. Furthermore it was believed to assist in dealing with social problems caused by disputes over religious issues in a more systematic manner. In April 2016, a Supreme Council for Islamic affairs or Fatwa Majlis was set up to replace the Fiqh academy which was established in 2009 by the government of President Nasheed. The mandate of this five member council was ensuring religious unity, raising public awareness on religious issues, conducting forums for religious scholars, and publishing a magazine with scholarly writings on contentious issues. However, despite such regulations no authority checks the content of fatwa's issued by individual religious scholars and groups.

"The thing is NGO's are registered under Ministry of Home Affairs. We (Ministry of Islamic Affairs) issue a permanent permit for Islamic scholars to preach and issue fatwas. So if a scholar wants to preach, they just have to obtain permission to use the building from the concerned authorities. So there is no one checking the content of such Fatwas and monitoring it. Fatwa council's work concerns the regulations of fatwas issued by them. Religious preaching is totally something different. And there never were any restrictions for individuals to issue fatwas or express their opinions. If not the society will lose their awareness on various issues." (Ibrahim, Deputy Minister of Ministry of Islamic Affairs)

There is a sort of hypocrisy in dealing with religious issues and values by both the State and religious authorities. For instance as pointed out in many of the local literature produced, the more conservative factions of the society have been increasingly propagating for a more private space for women in the society. However, when a teacher was dismissed by the government for wearing 'Nigab' (face veil) which is against the civil service dress code, it was the same faction who has been most active in voicing their concerns for such discrimination by the State. Moreover, the discrepancy between State actions towards secular and ultraconservative factions has also created much disharmony in the society. While the State has actively pursued to subdue the secular voices, it has been silent on actions and messages propagated by ultra-conservative factions that are in conflict with the Religious Unity Act. This has also led to fragmentation of the society on religious grounds.

There is also a lack of moderate counter-narratives against political instrumentalization of religion and expression of rigid or extreme religious discourses. Speaking on the subject Dr. Mohamed Shaheem Ali Saeed noted that: "Work is being done. But may be the effort that's being made is fee- 
ble. There are reasons for this also. For example security reason is one huge factor. You would know what happened to Dr. Afrasheem. And even several journalists have been attacked and even murdered. So there is no security for religious scholars even, here in the Maldives." (Saeed, 2019)

Nielsen argues that "cleric educational networks and career incentives influence whether clerics adopt Jihadi ideology. Well-connected clerics typically pursue comfortable careers within state-run religious institutions and they reject Jihadi ideology in exchange for continued material support from the state." This can also be witnessed in the Maldives where since transitioning in to democracy many of the activists including religious clerics had assumed government positions. Nielson further states that those clerics outside the state system directly appeals to lay audience often propagating radical ideologies. Moreover individuals seeking social support through friends and family under the guidance of spiritual leaders "become convinced that an extremist cleric or group offers the most authentic interpretation of Islam" (Nielsen, 2014). Speaking on lack of moderate opinions on religious issues Dr. Zakariyya noted that one reason for it is that religious scholars with moderate views do not have many followers willing to promote such views. For those who are moderate religion is a private affair, and as such lacks willingness to work with moderate religious scholars to promote such views.

"The truth is the reason why the circle of those propagating radical religious ideas is bigger is that they are very active. On the other hand the circle of those propagating more moderate religious thoughts is not at all active. The main reason for it is that those supporting moderate religious thoughts they don't have the time to mobilize and promote such ideas. For them religion is one's own private matter whereas those with supporting radical religious thoughts they are very strict to follow their religion. If it's a religious issue they are very quick to say yes and will come out very quickly." (Moosa, 2018).

Thus, in the context of the Maldives, fragmentation of religious narratives, paucity of balancing counter-arguments against radical ideologies, lack of monitoring of content with extreme views and relevant action against local religious networks disseminating such views creates an enabling environment for radical religious ideologies to flourish. Lack of action against clerics propagating radical views and Jihadi ideology may also be in part due to the political instrumentalization of religion.

\section{CONCLUSION}

As supported by the various literature on radicalization, lot of times radicalization takes place in individual or small circles often in mosques or in some other place. There is ample evidence that religious retreat camps are one of the avenues through which radical messages are conveyed. Often times the purpose of such camps are cited as religious education and awareness however taking note of the geography of the Maldives and smallness of Island communities it provides fertile ground for easy penetration of radical messages, especially through one on one conversations. The findings also points out that there are many systematic loopholes in dealing with Islamic radicalization in the Maldives. To name a few, lack of coordination among concerned authorities and trivialization of the problem at the national level and failure to monitor and take actions on radical activities carried out by religious NGOs and informal religious groups have led to the escalation of this phenomenon. Jihadi recruitment operations are carried out mostly by more sinister networks and are rather covert operations.

\section{LIMITATIONS AND RECOMMENDATIONS}

1) At present, there are divides among various religious factions of the society. Proliferation of diverging religious narratives also facilitate ambiguity on religious issues among lay people of the society. The opinions on religious stances of various scholars are influenced by the institution and country in which they studied. As such there are divides and doctrinal differences among many of the clerics. In order to address such differences a platform needs to be created where religious differences can be debated and discussed in harmony.

2) Government efforts also need to be strengthened in maintaining balancing moderate religious counterarguments on contending religious issues and ideologies through Ministry of Islamic Affairs and other oversight bodies dealing with religious issues in the country. There is also an increased belief that moderate or secular narratives on religious issues will be met with aggressive threats and actions by the ultra-conservative factions of the society. Thus, law enforcement agencies should be working on creating a more secure environment where all factions of the society can express their opinions in line with democratic values enshrined in the Constitution and the Religious Unity Act.

3) With the global reach facilitated by Internet it has become one of the key avenues through which radical and violent ideas are disseminated and absorbed by vulnerable individuals. The law enforcement agencies should find a right balance where they can monitor such content by engaging with the public as well as the Maldives Broadcasting Commission, without impinging on people's privacy and while upholding democratic values. 


\section{REFERENCES}

Alahoul, M. H. M., Azizan, N., \& Alwi, N. H. (2016). Factors that affect the use of Malaysian e-learning websites by visually impaired users in the transfer of Islamic knowledge. Journal of Advanced Research in Social Sciences and Humanities, 1(1), 30-40. doi:https://doi.org/10.26500/jarssh-01-2016-0104

Ayoob, M. (2004). Political islam: Image and reality. World Policy Journal, 21(3), 1-14. doi:https://doi.org/10.1215/ 07402775-2004-4011

Azhar, M. (2015). The concept of religious democracy as a new political philosophy for countries with moslem predominant. Journal of Advances in Humanities and Social Sciences, 1(1), 19-28. doi:https://doi.org/10.20474/jahss1.1.3

Christiansen, J. (2009). Four stages of social movements. New York, NY: Willey and John Son's.

Githens-Mazer, J., Lambert, R., Baker, A. H., Cohen-Baker, S., \& Pieri, Z. (2010). Muslim communities perspectives on radicalisation in Leicester, UK. Aarhus, Denmark: Centre for Studies in Islamism and Radicalisation (CIR).

Kruglanski, A. W., \& Webber, D. (2014). Psychology of radicalisation. Zeitschrift Fur Internationale Strafrechtsdogmatik, 5(7), 379-388.

Maldives Democracy Network. (2016). Preliminary assessment of radicalization in the Maldives. Retrieved from https:// urlzs.com/v3u8 (accessed on 15 July, 2017)

Maldives Police Service. (2018). Shama interview. Retrieved from https ://urlzs . com/kErs (accessed on 5 July, 2018)

McCauley, C., \& Moskalenko, S. (2017). Understanding political radicalization: The two-pyramids model. American Psychologist, 72(3), 205-216. doi:https://doi.org/10.1037/amp0000062

Minivan News. (2015). Politics new penal code will bury Islamic sharia. Retrieved from https://urlzs . com/RbGd (Accessed on 14 April, 2017)

Moosa, I. Z. (2018). Zakir musa has five militants with him, 20 others may be under Al-Qaeda sway: Jammu and Kashmir Police. Retrieved from https://urlzs . com/L6Fn (accessed on 14 July, 2018)

Naseem, A., \& Mohamed, M. (2014). Dhivehi sitee. Retrieved from https://urlzs . com/27KQ (Accessed on 15 July, 2018)

Neumann, P. R. (2011). Preventing violent radicalization in America. Retrieved from https://urlzs. com/kD8A (Accessed on 14 July, 2017)

Nielsen, R. (2014). Networks, careers, and the jihadi radicalization of Muslim clerics. Retrieved from https://urlzs . com/ V7Ps (accessed on 1 April, 2016)

Patel, F. (2011). Rethinking radicalization. New York, NY: Brennan Center for Justice at New York University School of Law.

Qianli, L. (2016). The impact of China-Central Asia relations on Xinjiang Uyghur Muslim riots. Journal of Advances in Humanities and Social Sciences, 2(2), 55-75. doi:https://doi.org/10.20474/jahss-2.2.1

Roy, O. (2018). Conversations with history. Retrieved from https://urlzs .com/xNeG (accessed on 14 August, 2018)

Saahar, S., Sualman, I., Hashim, M. A., \& Mohamed, W. A. W. (2017). Political advertising and young voters information needs. International Journal of Humanities, Arts and Social Sciences, 3(5), 215-222. doi:https://doi.org/10.20469/ ijhss.3.20004-5

Saeed, M. S. (2019). Forum on scientific miracles of the Quran. Retrieved from https://urlzs .com/i5sC (accessed on 15 March, 2019)

Veldhuis, T., \& Staun, J. (2009). Islamist radicalisation: A root cause model. Hague, Netherlands: Netherlands Institute of International Relations Clingendael. 